\title{
An overview of empirical research on ethics in entrepreneurial firms within the United States
}

An earlier version of this paper was presented at the 2008 ISBEE Conference in Cape Town, South Africa.

\begin{abstract}
Scholars recognise that entrepreneurs may encounter different ethical issues and pressures than managers in larger corporations. This has fostered empirical research aimed at assessing ethics in entrepreneurial settings in the United States. Our emphasis on empirical research with little attention paid to purely conceptual papers allows us to highlight the narrow definition of entrepreneurship used in the US and how US researchers distinguish between entrepreneurship and other types of small businesses. This differs greatly from many other countries, especially those in which researchers equate entrepreneurship with the study of small and medium sized enterprises (SMEs). Researchers in the US often distinguish ethics from corporate social responsibility (CSR), corporate social performance (CSP), stakeholder theory and stakeholder management with different theoretical models proposed in each of these areas. After discussing these various definitional issues, we review the empirical research on ethics in entrepreneurial firms, discussing what the results tell us, identifying gaps in prior research and concluding with recommendations for future research that draws more heavily on theoretical frameworks in the field of ethics.
\end{abstract}

Key words: ethics, entrepreneurship, ethical attitudes, ethical issues

\section{Introduction}

The vast majority of empirical research in business ethics has been conducted in large corporations, resulting in a fairly substantial body of knowledge. A recent review of the field of behavioural ethics summarises much of the

Melissa S. Baucus is an Associate Professor of management and entrepreneurship at University of Louisville. Her current research focuses on issues of concern to entrepreneurs with emerging ventures such as angel investing decisions, strategies for establishing legitimacy and ethical decision making, as well as misconduct and illegal behavior in entrepreneurial firms. She has published articles in Academy of Management Journal, Entrepreneurship Theory and Practice, Journal of Business Venturing, Journal of Business Ethics and other leading management journals.

Philip L. Cochran is the Associate Dean for Indianapolis Programs for the Kelley School of Business. He is the Thomas W. Binford Chair in Corporate Citizenship and serves as the Director of Indiana University's Randall L. Tobias Center for Leadership Excellence, Professor of Management at Indiana University's Kelley School of Business, and Professor of Philanthropic Studies at IU's Center on Philanthropy. large-firm ethics research (Trevino, Weaver \& Reynolds, 2006). An early empirical study of ethics in smaller firms (Longenecker \& Schoen, 1975) provided an indication that attitudes may vary among people in small versus large organisations. This led to questions regarding whether entrepreneurs possess different ethical values and attitudes, face different ethical issues, and make different ethical decisions than managers in large firms. Scholars have recently suggested that entrepreneurs starting new ventures might exhibit an inherent bias toward compromising their own values in order to succeed at any cost (Fisscher, Frenkel, Lurie \& Nijhof, 2005).

Scholarly interest in ethics and entrepreneurship has increased as illustrated by Issue 3 of the Ruffin series on ethics and entrepreneurship (Freeman \& Venkataraman, 2002) and a special issue of Journal of Business Ethics in 2005 featuring articles from the 2004 conference of the European Business Ethics Network (EBEN). These demonstrate a growing emphasis on ethics and entrepreneurship, particularly development of theoretical work and empirical studies by international scholars; however, the review here of empirical research on ethics and entrepreneurship in the US shows that we still know very little. Payne and Joyner (2006) illustrate the problem in the field when they review all of the empirical research that compares the ethics of managers versus entrepreneurs - all 11 studies - and eight of the 11 rely on small businesses rather than entrepreneurial firms. The broader focus of this review on studies of ethics in entrepreneurial firms in the US (by researchers at US universities) results in a somewhat larger number of empirical studies, but the amount of research in this area pales by comparison to the extensive body of empirical research conducted in large corporations.

Our obvious conclusion is that more research needs to focus on entrepreneurial firms but the recommendations presented here go beyond that. Sampling problems, use of research instruments that present decisions less likely to occur in entrepreneurial firms, and other methodological issues must be addressed. We also recommend greater reliance on theoretical frameworks in the ethics literature, applying them to the entrepreneurial context. We hope our review and recommendations will generate increased research on ethics in entrepreneurial firms, particularly studies that investigate different levels of analysis and research questions that have not yet received attention. 
Our paper begins by defining entrepreneurship and explaining how it differs from small business and related areas in the United States. This leads to a discussion of the growing role entrepreneurship plays in the US economy and calls for greater entrepreneurial activity as a source of economic growth and prosperity in the global economy. Entrepreneurship has a significant impact on US society, making it important to understand ethics within the entrepreneurial context. We touch on a few studies regarding how entrepreneurs regard their obligation to society while explaining that many US researchers delineate between ethics and corporate social responsibility (CSR), corporate social performance (CSP), stakeholder theory and stakeholder management. These distinctions matter for international researchers trying to publish in US academic journals so that we can compare research results across the globe. We conclude with a discussion of concerns about prior research methods, recommendations for improving research designs, and efforts to test some of the conceptual models of ethics in an entrepreneurial context.

\section{Defining entrepreneurs in the US}

Substantial debate in major entrepreneurship journals in the US centres on how to define entrepreneurship (cf. Brush, Manolova \& Edelmlan, 2008). Scholars focus on issues such as whether entrepreneurship must involve starting a completely new organisation, pursuing a relatively high growth rate for the enterprise, developing a management team without family members and so forth. One widely used definition of the field depicts entrepreneurship as, 'the scholarly examination of how, by whom, and with what effects opportunities to create future goods and services are discovered, evaluated, and exploited ... the study of sources of opportunities; the processes of discovery, evaluation, and exploitation of opportunities; and the set of individuals who discover, evaluate, and exploit them' (Shane \& Venkataraman, 2000:218). This definition, that can include entrepreneurial activities within large corporations, contrasts to definitions requiring an entrepreneur to start a new venture, such as: 'Entrepreneurship is the process in which one or more people undertake economic risk to create a new organisation that will exploit a new technology or innovative process that generates value to others' (Schramm, 2006:4). Although Schramm requires that an entrepreneur create a new organisation, he later states that, 'Entrepreneurship is a mindset' (2006:11) or way of thinking that opens people up to the idea that they could start a business. This notion of entrepreneurship as a mindset ties directly to research emphasising the cognitive aspects of entrepreneurship and the idea that entrepreneurs may have different ways of thinking and viewing the world around them that enable them to better identify and exploit economic opportunities (e.g. McGrath \& MacMillan, 2000).

We adopt Shane and Venkataraman's (2000) definition of entrepreneurship because it represents one of the broader ones in the field. This definition does not require an entrepreneur to create a completely new organisation so it can encompass corporate entrepreneurship, often defined as activities involved in exploiting new opportunities within the context of an existing organisation. In contrast to the definition offered by Schramm, it also does not require an entrepreneur to develop a new technology or innovation. This recognises that some entrepreneurs excel through imitative strategies in which they take an existing technology or business and find ways to improve upon it by offering better service, tailoring it to a niche market in the industry and so forth.

Entrepreneurs differ from small business owners (Ebert \& Griffin, 2005; Katz \& Green, 2007). Scholars in the US typically emphasise that entrepreneurs seek high growth while small business owners appear content with generating sufficient revenue to support the owners' personal goals and lifestyle (Katz \& Green, 2007). Some small business owners may even resist growing too large because it would require them to supervise lots of employees, create a more complex organisation with systems and procedures in place to effectively manage the operations, and reduce some of the owner's flexibility and autonomy. The US Small Business Administration defines a small business as an independent business with fewer than 500 employees. Entrepreneurs may start out with very small ventures but they will possess goals of growth, likely exhibit substantial growth over the first few years of the venture and continually innovate and search for new opportunities. Small business owners often operate lifestyle or hobby businesses and content themselves with maintaining existing markets and opportunities.

This distinction between entrepreneurs and small business owners has often been blurred, especially in early entrepreneurship research, with researchers using samples of owners or employees of small businesses and then drawing conclusions about entrepreneurial firms. This represents an issue discussed later in the area of ethics and entrepreneurship research. In recent years, entrepreneurship researchers in the US have been more vigilant about conducting research using samples of firms that meet various definitions of entrepreneurial firms. This contrasts with entrepreneurship research in Europe where the term SME - small and medium sized enterprises - describes entrepreneurial firms, small businesses, family firms and larger firms than included in US samples.

Medium and large firms that engage in entrepreneurial activity represent examples of corporate 
entrepreneurship for US researchers. Corporate entrepreneurship occurs when an existing medium or large sized firm starts a new venture within the context of their existing corporation. Some definitions of entrepreneurship by US scholars include corporate entrepreneurship, such as the one by Shane and Venkataraman (2000) used here or Covin and Miles' (1999) explication of entrepreneurship as a process of discovery and development of opportunities that allow an individual to create value through an existing firm or by establishing a new organisation. However, corporate entrepreneurship represents a separate stream of research because of unique characteristics of the phenomenon.

Corporate entrepreneurship differs in several key ways from an individual starting a venture independent of a corporation. Employees within an existing firm who want to start a new venture must successfully sell their idea to upper-level managers, acquire essential resources within the firm, and meet the corporation's goals for the new venture as well as their own goals. They operate within an established organisation structure, a longstanding culture or climate related to ethical behaviour and sometimes governed by codes of conduct. Corporate entrepreneurs often have access to more resources since the corporation has deeper pockets and a larger talent pool. A very important distinction involves the fact that a corporate entrepreneur will typically still have a job even if the new venture fails: the employer will find another opportunity or position for the employee. This makes corporate entrepreneurship unique in many ways compared to entrepreneurial ventures started by independent entrepreneurs. Researchers have developed separate models predicting corporate entrepreneurship (e.g. Dess \& Lumpkin, 2005; Zahra, 1991). Some studies have been done on ethics in corporate entrepreneurship settings (cf. Chau \& Siu, 2000; Kuratko \& Goldsby, 2004) but a complete review of that work is outside of the scope of this paper.

Entrepreneurship researchers in the US also delineate between entrepreneurial firms, franchise organisations and family businesses. Franchising represents a hybrid form of organisation that allows an individual to act as an entrepreneur in starting up an enterprise but reduces the entrepreneur's risk by providing a proven business formula and brand in exchange for a base fee and royalties. The franchisee does not have the level of autonomy possessed by an entrepreneur, however, since the franchisee must adhere to the franchisor's rules for setting up and running the business, and provide the products or services developed by the franchisor. Family businesses often start out as entrepreneurial ventures with a single family member creating the new venture; however, many family businesses operate for a number of years and move out of the entrepreneurial category when the founder's children, grandchildren or other relatives begin running the business. Some family businesses start out with multiple family members on the new venture team, creating unique issues and dynamics (e.g. family members may share ownership and profits while nonfamily managers do not) relative to entrepreneurial ventures started by a single entrepreneur or by unrelated individuals.

In sum, US researchers interested in empirically studying entrepreneurs and entrepreneurial processes typically try to select samples of entrepreneurs and not small business owners, franchisees, family-owned and operated businesses, or corporate entrepreneurs unless the goal of research involves comparing entrepreneurs with one or more of these other groups, for instance, to see how entrepreneurs versus small business owners perceive risk. Researchers outside of the US need to understand these distinctions in order to carefully select their research sample and accurately describe it when attempting to publish in US academic journals. These variations in types of entrepreneurial and other smaller ventures also complicate efforts to compare empirical results across countries.

\section{The role of entrepreneurs in the US}

Entrepreneurship plays a major role in the United States economy. A report prepared by the Small Business Administration states that in 2004: small firms employing less than 500 workers provided all of the 1.86 million net new jobs in the United States while large firms experienced a decline in jobs; small firms generated over half of the private non-farm gross domestic product in the US; and small firms with less than 500 employees comprise over 99\% of businesses in the US (Small Business Administration, 2008). As the economy weakened in 2007, small firms continued to provide most new jobs and the total number of self-employed individuals remained fairly constant (Small Business Administration, 2008). A study in the US funded by the Kauffman Foundation indicated that $10.5 \%$ of the working adult population was involved in starting a business or running a business that was less than three years old (Palmer, 2003). Men were more likely to engage in entrepreneurial activity with 1.6 males involved in a new venture for every female, and in the 18-24 year old group, males were almost three times as likely to be involved in new businesses than females in that same age group (Palmer, 2003). The number of women entrepreneurs has grown by $14 \%$ since 1997 , with over 6.2 million female-owned businesses in the US generating $\$ 1.2$ trillion in sales and employing 9.2 million people (US Newswire, 2003). These women-owned businesses experienced a 30\% growth in employment since 1997 while other businesses in the US grew by only $18 \%$.

The US economy has slowed considerably in the past several years with petroleum prices fluctuating, numerous large corporations such as General Motors 
suffering from major financial problems, food costs increasing and consumer confidence declining. Innovation and entrepreneurial activity has been touted by some as the best solution for dealing with global warming, poverty, and other world problems, as well as for growing and transforming the US economy. Carl Schramm, President of the Kauffman Foundation, asserts that innovation and entrepreneurship represent a 'secret' for maintaining the US position as an economic superpower and the primary way to assure prosperity, stability and peace around the world (2006). Schramm and other proponents of this view cite the long history of innovation and entrepreneurial activity in the US, dating back to Benjamin Franklin and Alexander Hamilton, as evidence of both the success and potential of entrepreneurship in addressing serious problems. Their argument will likely generate considerable debate among scholars but increasing investments intended to foster greater entrepreneurship demonstrate support for the belief that entrepreneurship represents a key force in economic progress.

Substantial investments in entrepreneurship have occurred in governments and education. Many states have developed programmes aimed at encouraging entrepreneurs to start ventures or relocate in their states. For instance, the state of Kentucky provided \$53 million and passed the Kentucky Innovation Act in 2000, requiring the state's Cabinet for Economic Development to create a Department of Commercialisation and Innovation that would take actions to increase the number of technology and research-intensive businesses in the state, increase jobs in these sectors and create clusters of innovation (Kentucky Cabinet for Economic Development, 2008).

Many government initiatives link to university activities since universities develop numerous new technologies and products that can be patented and commercialised. Universities benefit also from the increasing investment in entrepreneurship research and education by groups such as the Kauffman Foundation and Coleman Foundation. These groups have funded numerous endowed chairs for entrepreneurship faculty, provided research grants, and encouraged entrepreneurship education. The Kauffman Campus Initiative awarded grants of up to $\$ 5$ million to a group of universities to launch programmes aimed at integrating entrepreneurship across the university curriculum. This takes entrepreneurship education out of the Colleges of Business and extends it to other programmes across the campus to develop more individuals willing and able to engage in entrepreneurial activity. Entrepreneurship programmes have grown tremendously in the past decade with many universities creating undergraduate, masters and doctoral programmes; expanding existing entrepreneurship course offerings; participating in an increasing number of business plan competitions; and offering assistance to local entrepreneurs through consulting courses in which students, mentored by an entrepreneurship professor, apply their entrepreneurship knowledge to help entrepreneurs solve real world problems.

In summary, interest in entrepreneurship has grown tremendously in the US as many people recognise the critical role it plays in the economy and its potential to help address a wide variety of societal problems. Educational initiatives have expanded greatly in universities, state and federal governments have looked for ways to increase entrepreneurial activity, and private organisations provide resources to fund research and educational endeavors in entrepreneurship.

\section{Ethics versus stakeholder theory, CSR and CSP}

Researchers in the US typically differentiate between ethics and stakeholder management, corporate social responsibility (CSR) and corporate social performance (CSP). Business ethics researchers have conducted empirical investigations of a multitude of topics including levels of moral judgment (e.g. Elm \& Weber, 1994; Weber, 1996), moral reasoning (e.g. Weber \& Green, 1991), ethical decision making and punishment (e.g. Ashkanasy, Windsor \& Trevino, 2006; Trevino \& Youngblood, 1990), reactions to just and unjust punishment (Ball, Trevino \& Sims, 1994) and similar issues at the individual level of analysis. The extensive body of empirical research on ethics at the organisational level includes perceptions of ethical leadership (e.g. Trevino, Brown \& PincusHartman, 2003), the effect of organisational justice and ethics programmes on employees (Trevino \& Weaver, 2001), a survey of corporate ethics practices (Weaver, Trevino \& Cochran, 1999a), the influence of executive commitment and environmental factors on corporate ethics systems as forms of control (Weaver, Trevino \& Cochran, 1999b) and so forth. These research streams draw on the extensive literature in business ethics.

In contrast, research on stakeholder management builds on stakeholder theory beginning with Freeman's seminal work (1984) and followed by key extensions (e.g. Donaldson \& Preston, 1995; Mitchell, Agle \& Wood, 1997; Phillips \& Freeman, 2003). Entrepreneurship scholars often discuss issues such as how startup entrepreneurs can establish cognitive legitimacy with their stakeholders (Aldrich \& Fiol, 1994) but numerous opportunities exist for scholars to empirically test stakeholder theory in the entrepreneurial context. Entrepreneurship researchers have made important theoretical contributions in the area of stakeholder management. For instance, Sarasvathy and her colleagues focus on topics such as relationships between entrepreneurship, innovation and hardships imposed upon a firm's stakeholders (e.g. Dew \& Sarasvathy, 2007). In another example, scholars have used a network perspective to provide a conceptual explanation of how of entrepreneurs' relationships with 
stakeholders can assist the entrepreneurs in discovering opportunities (Vanderkerckhove \& Dentchev, 2005). The work by Dew and Sarasvathy illustrates that entrepreneurship differs from innovation in the United States since innovation exists in organisations of all sizes, not just entrepreneurial firms, and entrepreneurship includes more activities than just innovation.

Corporate social responsibility (CSR) and corporate social performance (CSP) have received extensive attention in the context of large corporations. We briefly touch on a few studies applying the corporate social responsibility literature to the entrepreneurial context in a later section. CSR and CSP involve greater emphasis primarily on the firm's relationships with external constituents while ethics scholars tend to study individual or within-organisation decisions and relationships. For instance, researchers have investigated whether the social responsibility of small firms varies from CSR in larger organisations (e.g. Chrisman \& Fry, 1982). Entrepreneurship scholars interested in studying CSR or CSP need to ground their empirical work in the extensive literature on CSR or CSP, depending on which construct they choose to measure.

\section{Ethics in entrepreneurship}

The discussion of differences between ethics, stakeholder theory, CSR and CSP illustrates that each represents a distinct literature within the field of business and society. The next section explains our decision to focus solely on ethics in the entrepreneurial context, specifically empirical research, in order to highlight the opportunity for scholars to begin to fill the gap that exists in this area. A review of the five areas of empirical research on ethics and entrepreneurship follows this discussion.

\section{Research conducted in and by scholars in the US}

A number of articles on ethics and entrepreneurship have appeared in high-quality journals that focus on ethics as well as those publishing work in entrepreneurship. This complicated our effort to identify empirical studies that fit definitions of entrepreneurship used in the US and our restriction of range to ethics research. Some very interesting research on ethics and entrepreneurship remains conceptual such as a model that integrates the spirit of entrepreneurial activity and moral decision making (Buchholz \& Rosenthal, 2005) or the many other articles by non-US scholars that appear in the same special issue of Journal of Business Ethics as the Buchholz and Rosenthal one. Our objective involved highlighting how little empirical research US scholars have done on ethics in entrepreneurial firms in the United States. We acknowledge the increasing number of conceptual papers that have been reviewed in other places (e.g. Freeman \& Venkataraman, 2002; Hannafey, 2003) and a growing number of empirical studies by international scholars, including some that appear in the Ruffin Series Number 3 (Freeman \& Venkataraman, 2002). For instance, one conceptual paper by an international author (Wempe, 2005) suggests that tension between values (or ethics) and business may provide opportunities for entrepreneurs; yet few US entrepreneurship scholars focus on unethical business opportunities or ventures. The conceptual work proposes numerous interesting relationships that need to be empirically tested in entrepreneurial organisations.

Research purporting to examine ethics in entrepreneurial firms can be grouped into five major categories: (i) ethical attitudes of entrepreneurs, sometimes comparing attitudes of entrepreneurs with those of managers; (ii) ethical issues encountered by entrepreneurs; (iii) ethical decision making; (iv) ethical climate and organisational factors; and (v) type of entrepreneurial activity and the entrepreneur. We review research in each category, focusing on what these studies appear to tell us and ways to address limitations of prior research in future research. Studies using samples of small businesses were included here since some of those firms were likely entrepreneurial by definition (e.g. high growth new ventures), but researchers did not gather data to distinguish between the two groups of firms.

\section{Ethical attitudes of entrepreneurs}

One of the first investigations of ethics in smaller firms was conducted by Brown and King (1982), looking at how the ethics of small business people compare to those of managers in larger firms and to the general population. Their study suggests that across the board, people view individuals in small business as having the highest ethical standards, with all groups of respondents ranking small business people higher than physicians, corporate employees and government officials (Brown \& King, 1982). An interesting aspect of this study involves the fact that respondents rank ordered the ethics of each group based on their perceptions but respondents were not asked about their actual level of knowledge or the basis for their perceptions of each group. Misconduct by large corporations and government officials appears frequently in the media so that may account for respondents perceiving these two groups as having lower ethical attitudes. The study also relied on small business people rather than entrepreneurs.

Two studies extended Brown and King's work, looking at ethical attitudes among entrepreneurs and comparing them against those of managers. The first study asked 165 entrepreneurs and 128 managers to respond to 12 vignettes and seven scenarios (Bucar \& Hisrich, 2001). Entrepreneurs exhibited higher ethical attitudes in responding to these situations than managers. A followup study (Bucar, Glas \& Hisrich, 2003) relied on the same research instrument to compare the initial US sample of entrepreneurs and managers (2001) with a new sample of 
82 managers in Slovenia and 159 entrepreneurs in Russia. Results indicate that US respondents - both entrepreneurs and managers - have higher ethical attitudes than those in Slovenia and Russia, and entrepreneurs and managers in Slovenia and Russia did not differ significantly from one another on their ethical attitudes (Bucar et al., 2003). The researchers did not address the question of whether their scenarios reflected ethical virtues or universal character traits that would apply across all cultures. The results for international respondents may be due to the scenarios themselves rather than reflecting actual differences in ethical attitudes.

In sum, the three studies investigating ethical attitudes appear to suggest that entrepreneurs and small business people may possess higher ethical attitudes than managers and the general population. As Payne and Joyner (2006) note, the research methodology used in these studies of asking respondents directly about ethics may elicit different attitudes than respondents actually hold (e.g. socially desirable responses) and respondents' decisions and behaviours may vary greatly from their espoused attitudes. On the other hand, entrepreneurs can benefit from understanding how the general public perceives their ethics. We also know little about the importance entrepreneurs place on ethics and strategies they use to manage stakeholders' perceptions of their ethics. These represent fruitful areas for research.

\section{Ethical issues for entrepreneurs}

One of the most researched areas involving ethics and entrepreneurs focuses on the ethical issues and situations encountered by entrepreneurs. Two early studies in this area involved an effort to learn more about whether the ethical situations encountered by entrepreneurs differ from those faced by others in society and whether entrepreneurs respond any differently than other people. In the first study, Longenecker (1988) provided respondents with 16 business decisions or short scenarios and respondents rated the acceptability of them using a seven-point scale ranging from never acceptable to always acceptable. Longenecker compared the 168 respondents who said they were self-employed with 1866 people not self-employed, concluding that respondents exhibited no significant differences on nine of the decisions. On two decisions, entrepreneurs appear more ethical and on five decisions, entrepreneurs reported less ethical responses. Longenecker indicates that entrepreneurs may focus more on the direct financial benefits for themselves in these five cases, illustrating ethical egoism or self-interested behaviour. This led to a follow-up analysis of other sub-samples within the same dataset (Longenecker, McKinney \& Moore, 1989) that compared 572 managers in small businesses of less than 100 employees with 785 employees in firms employing more than 1000 people. Results of this analysis showed small business employees viewed six ethical issues or situations as less acceptable than larger firm employees, but on another six ethical issues, the small business employees appeared less ethical. Longenecker and his colleagues (1989) conclude that these differences may indicate that some ethical issues in the instrument appear more relevant to small business employees while other issues have greater relevance for employees of large corporations. Although the two studies taken together seem to show that people working in small businesses may view some unethical issues or responses to situations as more acceptable than employees in large firms, the issues in the study may not consistently apply to small businesses and we still know little about ethical issues in entrepreneurial firms.

The instrument developed by Longenecker et al. (1989) was subsequently tested by Hornsby, Kuratko, Naffziger, LaFollette and Hodgetts (1994) who wanted to see if small business owners faced these ethical issues and if there were underlying dimensions among the issues. Their analysis of survey responses from 282 small business owners in the Midwestern and Southern US confirmed the four factors from the Longenecker et al. (1989) study, although they threw out one factor scale because of very low reliability (0.32). They concluded that small business owners encounter three types of ethical issues that they labelled business development, money-related theft, and administrative decision making. The reliabilities of these three factors, $0.65,0.65$ and 0.58 (all well below generally accepted standards), suggested that Longenecker et al.'s may have expressed a valid concern that the ethical issues in the instrument may not consistently apply to small businesses. A later study of 401 entrepreneurs and small business owners in the Midwestern US, all with less than 500 employees, gathered data using the 16 items in the Longenecker et al. (1989) instrument, factor analysed the data and concluded that ethical issues in small firms represents two dimensions: administrative/ instrumental and profit/personal gain (Kuratko, Goldsby \& Hornsby, 2004). An interesting extension in the study by Kurtako and his colleagues (2004) entailed asking small business owners to indicate the amount of time they spend on various stakeholder groups; results show owners consider their primary stakeholders to include customers and employees. The amount of time spent on various stakeholder groups (e.g. employee centred or customer centred) did not relate to the types of unethical behaviours but did correlate with satisfaction with stakeholder relationships: owners spending more time on suppliers, government or academic institutions expressed less satisfaction with stakeholder relationships than those who devoted more time to customers, stockholders or banks/lenders (Kuratko et al., 2004). This study appears to be the only empirical research conducted using stakeholder 
theory and attempting to examine relationships among stakeholder orientation and ethical or unethical behaviours. We view this as a very promising area for future research.

Another group of researchers have considered how the external environment in which small firms operate may impact their ethical values and the ethical issues they encounter. Smith and Oakley (1994) used the Longenecker et al. (1989) instrument to examine whether the size of the community affects a small business owner's ethical values. They obtained surveys from 110 owners of small businesses in a metropolitan area near a state capital and 99 owners of firms in nonmetropolitan areas; their analysis of responses to the Longenecker et al. (1989) instrument indicated that small business owners in non-urban areas appear to have higher ethical values than those in urban areas (Smith \& Oakley, 1994). The reasons for these differences remain unclear but could involve small business owners feeling a stronger sense of community in a non-urban area or simply that they perceive any unethical behaviour may be more easily noticed and brought to the attention of the firm's stakeholders and the community. One of the key contributions of Smith and Oakley's work entails focusing attention on the external environment in which the firm operates. Additional studies could examine the urban versus non-urban dimension or could include other measures of the firm's environment such as scarcity/munificence, dynamism, stage of industry evolution and so forth. Theories of corporate illegality developed for large firms suggest that both pressure or opportunity in the firm's industry environment may encourage them to engage in illegal or unethical behaviours (e.g. Baucus \& Near, 1991). These theories could be adapted to small firms, allowing researchers to explore contextual variables related to ethical behaviour.

\section{Ethical decision making}

Ethical decision making represents one of the few research streams within the entrepreneurship and ethics area that relies fairly heavily on ethical theories and research. One of the first studies in this area used the multidimensional ethics scale developed by Reidenbach and Robin (1991) to examine the ethical dimensions used by small business owners and managers and compared them to those of consumers: results indicate no significant differences between the two groups on the dimensions used (Humphreys, Robin, Reidenbach \& Moak, 1993). Both groups rely mainly on moral equity justice and fairness - in judging what represents ethical behaviour and less on relativism (acceptability in culture and tradition) and contractualism (adheres to or violates an unwritten or unspoken contract), although small business owners appeared to place somewhat more weight on the latter two dimensions than customers did. Payne and Joyner (2006) extended this research in two ways.
Instead of prompting respondents with ethical decisions or issues and possibly triggering social desirability biases, they reanalysed interview data they had collected from ten successful business founders - entrepreneurs with growing ventures - when they conducted a prior study of new venture creation and development (Payne \& Joyner, 2006). They also developed four categories of decisions that encompass ethics using Kant's and Rawls' theories and used these four categories in their content analysis of the data to show that entrepreneurs encounter ethical issues associated with: (i) individual entrepreneurial values of integrity, honesty and a strong work ethic; (ii) employee programmes such as training, assistance, benefits and empowerment; (iii) quality products and customer service; and (iv) accountability to the external environment or external stakeholders (Payne \& Joyner, 2006). The research design used by Payne and Joyner represents one of the few that allows entrepreneurs to generate the ethical issues of concern to them rather than prompting them with issues identified by researchers. We recommend that more research in this area rely on interviews and methods that permit entrepreneurs to provide the ethical issues that most concern them since that will likely produce some issues and dimensions not yet identified. Our recommendation receives support from a study by Vyakarnam, Bailey, Myers and Burnett (1997) in the United Kingdom that used focus groups of four to eight small business owners to learn more about the ethical issues and dilemmas they face: results show personality issues, conflicts of interest, and stakeholder obligations versus responsibility to the business were key problem areas. Some of these issues have not been fully incorporated in research instruments designed to investigate ethical issues in entrepreneurial or small business firms.

One surprise in research on ethics and entrepreneurship involves the relative lack of attention paid to levels of ethical or moral decision making. Teal and Carroll (1999) conducted an early study in this area, using Rest's Defining Issues Test to examine the ethical reasoning of 26 entrepreneurs. Their results indicate that entrepreneurs have a somewhat higher level of moral reasoning than middle managers and the general population, using measures of these latter two groups obtained from prior research on moral reasoning (Teal \& Carroll, 1999). The small sample size of their study and having a sample consisting of $62 \%$ females may have affected the results, suggesting that researchers should replicate and extend this research. Entrepreneurs often start their own firms in order to have control over their lives rather than working for and answering to someone else so we might expect them to reason at a level above Stage 3, that used by the majority of the general population, where group norms exert a heavy influence on ethical decision making or reasoning; however, research needs to demonstrate that entrepreneurs do reason at higher levels and why this occurs. 
A recent investigation examines the role moral imagination plays in incorporating ethics into decisions of high uncertainty (McVea, 2009). McVea builds on work by Sarasvathy and her colleagues suggesting that entrepreneurs use unique cognitive approaches when solving strategic problems they face (Sarasvathy, 2001; Sarasvathy, Simon \& Lave, 1998). One of the most notable contributions of McVea's (2009) research to the area of ethics and entrepreneurship involves his use of a qualitative research methodology: verbal protocol analysis and interviews were conducted as 12 entrepreneurs and a comparison group of MBA students made decisions in the context of an ethically challenging scenario. Results of this study indicate that entrepreneurs appear to use a high degree of moral imagination and initially frame the situation as involving ethics while MBA students use less moral imagination and primarily a decision frame that emphasises financial risk (McVea, 2009). This research suggests that entrepreneurs may engage in different cognitive processes and framing than other business people, highlighting an area in need of further study.

One study of decision making biases among entrepreneurs did not focus directly on ethical decision making but the situations used in the research encompassed ethical issues so we have included the study in this review. Busenitz and Barney (1997) asked 124 entrepreneurs and 95 managers to respond to five questions on death rates and accidents, and their data show that entrepreneurs rely more heavily in the overconfidence and the representativeness heuristics when making decisions than do managers. This study highlights the need for research linking cognitive biases to ethical decision making, particularly among entrepreneurs. If entrepreneurs more frequently engage in decision making biases than managers, they may inadvertently make unethical decisions. One approach to investigating this issue involves presenting entrepreneurs with a series of decisions similar to those in the Busenitz and Barney research with one set including ethical dimensions and another set excluding the ethical dimensions to see if entrepreneurs consistently engage in biases or if the presence of ethical dimensions triggers different decision making processes.

\section{Ethical climate and organisational factors}

Four research studies have examined the ethical climate or ethical organisation of entrepreneurial firms in an effort to determine whether entrepreneurs or small business owners differ in their ethical orientation than other managers. The first study (Welsh \& Birch, 1997) used the 26-item ethical climate questionnaire developed by Victor and Cullen (1988) to examine the ethical climate in 26 small businesses and compare them to the ethical climates in larger firms in the Victor and Cullen sample. Welsh and Birch also included a 20-item measure of Machiavellianism in order to look at how small business owners use power in their organisations. Results indicated small business owners were less likely to abuse power than other people, more likely to view ethical values as universal rather than relativistic, and were more likely to emphasise caring and independence dimensions of ethical climate than other people (Welsh \& Birch, 1997). A follow-up study supported the lack of an instrumental ethical climate in entrepreneurial firms shown in the Welsh and Birch sample but did not indicate that entrepreneurs use an independence or caring climate (Neubaum, Mitchell \& Schminke, 2004). The results from 304 employees in 45 entrepreneurial firms showed new firms were more likely to have rules-oriented ethical climates compared to older entrepreneurial ventures, and new firms were less likely to have instrumental or independence ethical climates (Neubaum et al., 2004). One explanation for the conflicting results of these two studies may be that Welsh and Birch relied on small businesses and did not examine the age of those firms whereas Neubaum and his colleagues categorised by age using two variables, a dichotomous one for new versus not new firm and a continuous variable for the age of the firm in years. The two variables for age produced different results in the analysis. This may mean that age represents a more complex variable than expected and that age could be a proxy for another unmeasured variable such as organisation size or organisation complexity such as ethical rules, procedures and compliance systems that become instituted as the firm grows and ages.

Firm age was recognised in a study of ethical climate that examined how ethical climate changes as a firm grows and evolves. Researchers (Morris, Schindehutte, Walton \& Allen, 2002) examined ethical climate, ethical development, Machiavellianism, locus of control and tolerance of ambiguity in 227 small firms that had fewer than 500 employees and had been in existence for less than 15 years. Their data showed firms fall into four categories in terms of their approach to ethics, ethical programmes and ethical policies: (i) 'deficients' or firms with very few ethical policies and programmes, little emphasis on ethics and infrequent discussions of ethics were most common, making up $47 \%$ of firms; (ii) 'pain and gain' firms, a modest $7 \%$ of the sample, that exhibited many similarities to 'deficients' in terms of institutionalising ethics but they took ethics very seriously and relied on rewards and punishments as well as stories of exemplary ethical behaviour; (iii) 'core proponents' of ethics that have established ethical policies but have not yet instituted many of the aspects of an ethical climate which included $26 \%$ of the sample; and (iv) 'superlatives' or the $21 \%$ of the firms in the sample that indicated they had most of the ethical policies and programmes on the research instrument that encompass an ethical climate (Morris et al., 2002). These results parallel research by Reidenbach and Robin 
(1991) maintaining that large firms vary in terms of their stage of moral reasoning so that more advanced firms exhibit ethical climates consistent with higher levels of moral reasoning.

The notion of entrepreneurial firms evolving in terms of their ethical climate was the focus of another study of ten successful high growth entrepreneurial firms that had been in operation for at least five years (Joyner, Payne \& Raiborn, 2002). These researchers grounded their investigation in Paine's (1994) ethical framework in order to determine whether entrepreneurial firms rely on a legal compliance strategy or if they have evolved to an integrity strategy. Results showed all ten entrepreneurs exhibited a legal compliance strategy by adhering to the letter of the law, and eight of the ten firms had gone far beyond this to demonstrate a number of dimensions of an integrity strategy as well; the remaining two firms had a few characteristics of an integrity strategy but had not gone as far beyond legal compliance (Joyner et al., 2002). These results appear to support research on entrepreneurs' ethical attitudes, indicating that entrepreneurs appear very concerned about ethics and ensuring that their firms support ethical behaviour.

In sum, the research on ethical climates and ethical organisations appears to indicate that entrepreneurial firms go through an evolutionary process, gradually institutionalising an ethical climate in the procedures and policies of the firm. Researchers can extend this stream by looking at entrepreneurial firms in different industry environments to see if the environment and industry culture influence the development of an ethical organisation climate since prior research has paid little attention to the context within which the sampled firms operate. Additionally, the studies reviewed here relied on entrepreneurs and small business people reporting their use of ethical policies and programmes and this could lead to self-report bias so future research should examine archival data or corporate documents to see if entrepreneurs have actual practices in place to support ethical behaviour.

\section{Type of entrepreneurial activity and the entrepreneur}

Entrepreneurship researchers have paid little attention to the ethics of entrepreneurial activity, with most researchers operating on the implicit assumption that entrepreneurs add value to society by exploiting opportunities in the environment. Baumol (1990) argued the entrepreneurial activities fall into three categories: (i) productive, such as those that involve innovations; (ii) unproductive, including rent-seeking activities; and (iii) destructive or those that involve criminal activities. Although Baumol did not discuss the ethics associated with activities in each of these categories - something ethics researchers should do - the third category of destructive activities appears fairly clearly to involve unethical behaviour, while unproductive activities in the second category may encompass questionable ethical behaviours.
A study by Hall and Rosson (2006) supports the distinction between different types of entrepreneurial activities with spam demonstrating destructive entrepreneurship, music file sharing providing an example of unproductive entrepreneurship, and Internet pharmacies illustrating productive or innovative entrepreneurial activity. These researchers conducted a case study of these three entrepreneurial endeavors and concluded that technological turbulence creates entrepreneurial opportunities as well as ethical issues and that new firms operating in these environments must establish legitimacy to survive; stakeholders appear much less likely to grant legitimacy to entrepreneurs engaged in less ethical - unproductive or destructive - activities (Hall \& Rosson, 2006). This initial study, while limited to a very small sample and exploratory in nature, suggests that researchers need to explore more fully the ethics involved in various entrepreneurial activities. We need to develop criteria for assessing the ethics of entrepreneurial activities, for instance, to determine whether music downloading constitutes an unethical and illegal activity or merely an illegal one and whether payday advancement businesses (i.e., loaning money to low-income individuals at very high rates of interest until the individuals receive their next paycheck) represents ethical or unethical forms of entrepreneurship.

We cannot simply assume that entrepreneurship by definition encompasses only ethical activities. Brenkert's (2009) recent discussion of rule-breaking within a virtue ethics framework adds a novel perspective, raising questions about whether and when rule-breaking in an entrepreneurial context constitutes unethical conduct. Researchers need to extend this work, as well as explore issues such as whether entrepreneurs engaged in more ethical purposes or endeavors have higher profitability, whether certain types or degrees of rule-breaking impact the ease with which entrepreneurs establish legitimacy with and acquire essential resources from their stakeholders and so forth.

The relationship between entrepreneurship and prior ethical or unethical behaviour was examined in a recent study (Zhang \& Arvey, 2009). The results of their investigation of 60 entrepreneurs and 105 managers indicate that modest versus severe rule breaking as an adolescent relates to being an entrepreneur as an adult (Zhang \& Arvey, 2009). This preliminary research, combined with work on entrepreneurial activity as rule breaking, represents an area that warrants further empirical investigation. Researchers need to examine illegal entrepreneurial ventures, differences between highly novel entrepreneurial firms that by definition engage in rule-breaking versus imitative new venture that conform to industry rules, and relationships among rule breaking as an adolescent or manager in Corporate America versus as an entrepreneur starting and running a new venture. 


\section{Corporate social responsibility and entrepreneurship research}

Corporate social responsibility (CSR) has received little attention by entrepreneurship researchers, possibly because of the label 'corporate' in the term, which implies more established organisations. An early study by Wilson (1980) investigated 180 small business owners and managers in larger firms to learn more about how small business owners view their responsibilities to society. Wilson developed 541 statements about CSR and respondents most frequently selected those involving responsibilities to customers as part of a small business' social responsibility. Small business owners appeared to fall into two types, Type P or the $88 \%$ of the sample that were profit-oriented; and Type V, $12 \%$ of those in the sample, made up of owners concerned about other values in addition to profitability (Wilson, 1980). These results initially appear to contrast greatly with those of Joyner et al. (2002) that indicated entrepreneurs went beyond legal compliance to focus on integrity in their firms; however, Wilson's data may emphasise the end results or goals of entrepreneurs or small business owners while Joyner et al.'s results may focus more on the means or how entrepreneurs go about accomplishing their goals.

A second study by Chrisman and Fry (1982) extended Wilson's research. This study relied on 19 items in the four categories used by Wilson (1980) to examine attitudes about CSR among 51 small business people and compare them to attitudes among 65 people in the general population. One item in the study asked respondents to provide a definition of corporate social responsibility and the authors concluded that small business people better understand CSR of small business because only $16 \%$ of small business people did not respond to the item while $26 \%$ of the general population did not provide a definition of CSR for small business. The authors' conclusion does not follow logically from their methodology but they raise an important issue that warrants additional study: How well defined is CSR for small firms? We also do not know the extent to which entrepreneurs and the public in general agree on the CSR of small businesses. For instance, we lack data on whether establishing an entrepreneurial venture in an area with little economic activity to help improve the area rather than in an already prosperous part of town represents a form of social responsibility. Entrepreneurs could benefit greatly by better understanding the expectations of society and how these may or may not agree with their own understanding of the CSR of entrepreneurs.

One study has investigated the corporate social performance of firms, comparing 202 non-family and 59 family firms that appeared on the Standard and Poor's 500 for ten years (Dyer \& Whetten, 2006). These firms, while family owned, experienced high growth so they can also be considered entrepreneurial ventures. Dyer and Whetten (2006) used KLD data on corporate social performance to show that family firms appear more socially responsible than non-family firms, and that family firms had significantly fewer product, environmental and employee concerns - three social concern measures than non-family firms. This recent study hopefully will foster additional research focusing on CSR or ethical behaviours of firms, relying on more objective data rather than surveys asking entrepreneurs or business owners to report on their attitudes and behaviours. Dyer and Whetten's study (2006) needs to be replicated in additional entrepreneurial firms and researchers may want to include variables for the type of capital used to finance the firm since venture capital backed firms may behave differently in terms of CSR than publicly traded firms. Family controlled firms may permit entrepreneurs (e.g. the head of the family) to engage in greater CSR than entrepreneurs who must meet the expectations of outsiders who invested in the firm.

This discussion does not represent all of the research on CSR in entrepreneurial organisations. Instead, it illustrates the types of questions entrepreneurship scholars could examine. One interesting extension of the research by Dyer and Whetten (2006) could involve comparisons of family versus entrepreneurial firms run by founders versus corporations led by professional managers to see which exhibit the highest levels of CSR, controlling for firm size and age.

\section{Conclusion}

Our review of empirical studies of ethics and CSR in entrepreneurial firms indicates that researchers have initiated several streams of research. Their results, if believed, seem to suggest that entrepreneurs and small business people espouse fairly high ethical values, encounter a number of ethical issues in starting and running a new venture, establish organisations to support the existence of an ethical climate as their firm evolves, and emphasise CSR by their firms. However, the small number of studies, heavy reliance on selfreports from small business employees as well as owners and entrepreneurs, research instruments that have not been shown to be valid and reliable, and use of surveys and scenarios that ask about ethics in ways that elicit social desirability bias, raise questions about what we can conclude from this research. The most important conclusions seem to be that each stream of research warrants further attention, numerous opportunities exist to examine relevant and important questions within each stream, and researchers can make significant contributions by integrating theoretical perspectives from the business and society field as a stronger grounding for research in this area.

One difficulty faced by scholars interested in studying ethics in entrepreneurial organisations involves the need to possess knowledge of the literature in each 
discipline. We recommend that entrepreneurship scholars consider applying and empirically testing one of the widely cited conceptual models of ethics (e.g. Jones, 1991; Jones \& Ryan, 1998; Trevino, 1986), although this will require researchers to consider how the entrepreneurial context may differ from that of large corporations. Much of the research in the ethics discipline could be transferred to and tested in an entrepreneurial context (cf. Brown, Trevino \& Harrison, 2005). It may be easier to begin by empirically testing arguments offered in many of the conceptual articles on ethics and entrepreneurship, such as the one by Rutherford, Buller and Stebbins (2009) that discusses the ethical boundaries entrepreneurs may face when trying to build legitimacy for their new ventures, or the other conceptual work highlighted earlier in this article. International scholars have also conducted interesting research on ethics and entrepreneurship that can be replicated in entrepreneurial firms in the US For instance, Bryant's (2009) research examining relationships between self-regulation and moral awareness among Australian entrepreneurs could be studied with US entrepreneurs to see what differences may exist across national borders. A final recommendation involves the need for greater collaboration among entrepreneurship and ethics scholars. Research teams with scholars from each discipline can more easily bridge the knowledge gaps that exist and likely generate insightful research questions, as well as develop better research designs.

\section{References}

Aldrich, H. \& Fiol, M. 1994. Fools rush in? The institutional context of industry creation. Academy of Management Review, 19(4): 645-670.

Ashkanasy, N.M., Windsor, C.A. \& Trevino, L.K. 2006. Bad apples in bad barrels revisited: Cognitive moral development, just world beliefs, rewards, and ethical decision-making. Business Ethics Quarterly, 16(4): 449.

Ball, G.A., Treviño, L.K. \& Sims, H.P. Jr. 1994. Just and unjust punishment incidents: Influences on subordinate performance and citizenship. Academy of Management Journal, 37(2): 299-322.

Baucus, Melissa S. \& Near, Janet P. 1991. Can illegal corporate behavior be predicted? An event history analysis. Academy of Management Journal, 34, 1-28.

Baumol, W. 1990. Entrepreneurship: Productive, unproductive, and destructive. Journal of Political Economy, 98(5): 893-921.

Brenkert, G.G. 2009. Innovation, rule breaking and the ethics of entrepreneurship. Journal of Business Venturing, 24: $448-464$.

Brown, D.J. \& King, J.B. 1982. Small business ethics: Influences and perceptions. Journal of Small Business Management, January: 11-18.

Brown, M.E., Trevino, L.K. \& Harrison, D.A. 2005. Ethical leadership: A social learning perspective for construct development and testing. Organizational Behavior and Human Decision Processes, 97(2): 117.
Bryant, P. 2009. Self-regulation and moral awareness among entrepreneurs. Journal of Business Venturing, 24: 505-518.

Brush, C.G., Manolova, T.S. \& Edelman, L.F. 2008. Separated by a common language? Entrepreneurship research across the Atlantic. Entrepreneurship Theory \& Practice, March: 249-266.

Bucar, B. \& Hisrich, R.D. 2001. Ethics of business managers vs. entrepreneurs. Journal of Developmental Entrepreneurship, 6(1): 59-82.

Bucar, B., Glas, M. \& Hisrich, R.D. 2003. Ethics and entrepreneurs: An international comparative study. Journal of Business Venturing, 18: 261-281.

Buchholz, R.A. \& Rosenthal, S.B. 2005. The spirit of entrepreneurship and the qualities of moral decision making: Towards a unifying framework. Journal of Business Ethics, 60: 307-315.

Busenitz, L.W. \& Barney, J.B. 1997. Differences between entrepreneurs and managers in large organizations: Biases and heuristics in strategic decision making. Journal of Business Venturing, 12: 9-30.

Chau, L.L. \& Siu, W. 2000. Ethical decision-making in corporate entrepreneurial organizations. Journal of Business Ethics, 23(4): 365-375.

Chrisman, J.J. \& Fry, F.L. 1982. Public versus business expectations: Two views on social responsibility for small business. Journal of Small Business Management, January: 19-26.

Covin, J.G. \& Miles, M.P. 1999. Corporate entrepreneurship and the pursuit of competitive advantage. Entrepreneurship Theory and Practice, 23: 47-63.

Dess, G.G. \& Lumpkin, G.T. 2005. The role of entrepreneurial orientation in stimulating effective corporate entrepreneurship, Academy of Management Executive, 19(1): 147.

Dew, N. \& Sarasvathy, S.D. 2007. Innovations, stakeholders and entrepreneurship. Journal of Business Ethics, 74: 267-283.

Donaldson, T., \& Preston, L. E. 1995. The stakeholder theory of the corporation: Concepts, evidence, and implications. Academy of Management Review, 20: 65-91.

Dyer, W.G., Jr. \& Whetten, D.A. 2006. Family firms and social responsibility: Preliminary evidence from the S\&P 500. Entrepreneurship Theory and Practice, November: 785-802.

Ebert, R.J. \& Griffin, R.W. 2005. Business essentials. Englewood Cliffs, NJ: Prentice-Hall.

Elm, D.R \& Weber, J. 1994. Measuring moral judgment: The moral judgment interview or the defining issues test? Journal of Business Ethics, 13(5): 341-355.

Fisscher, O., Frenkel, D., Lurie, Y. \& Nijhof, A. 2005. Stretching the frontiers: Exploring the relationships between entrepreneurship and ethics. Journal of Business Ethics, 60: 207-209.

Freeman, R. E. 1984. Strategic management: A stakeholder approach. Boston: Pitman.

Freeman, R.E. \& Venkataraman, S. 2002. Ethics and entrepreneurship: The Ruffin Series, Volume 3. Charlottesville, VA: Philosophy Documentation Center.

Hall, J. \& Rosson, P. 2006. The impact of technological turbulence on entrepreneurial behavior, social norms and ethics: Three Internet-based cases. Journal of Business Ethics, 64: 231-248. 
Hannafey, F.T. 2003. Entrepreneurship and ethics: A literature review. Journal of Business Ethics, 46(2): 99-110.

Hornsby, J.S., Kuratko, D.F., Naffziger, D.W., LaFollette, W.R. \& Hodgetts, R.M. 1994. The ethical perceptions of small business owners: A factor analytic study. Journal of Small Business Management, October: 9-16.

Humphreys, N., Robin, D.P., Reidenbach, R.E. \& Moak, D.L. 1993. The ethical decision making process of small business owner/managers and their customers. Journal of Small Business Management, July: 9-22.

Jones, T.M. 1991. Ethical decision making by individuals in organizations: An issue-contingent model. Academy of Management Review, 16(2): 366-395.

Jones, T.M. \& Ryan, L.V. 1998. The effect of organizational forces on individual morality: Judgment, moral approbation, and behavior. Business Ethics Quarterly, 8(3): 431-445.

Joyner, B.E., Payne, D. \& Raiborn, C.A. 2002. Building values, business ethics and Corporate Social Responsibility into the developing organization. Journal of Developmental Entrepreneurship, 7(1): 113-131.

Katz, J.A. \& Green, R.P. 2007. Entrepreneurial small business. NY: McGraw Hill Irwin.

Kentucky Cabinet for Economic Development. 2008. Technology and innovation overview. [Online.] Available: http://www.thinkkentucky.com/DCI/DCIHome.aspx/. Accessed on 27 June 2008.

Kuratko, D.F. \& Goldsby, M.G. 2004. Corporate entrepreneurs or rogue middle managers? A framework for ethical corporate entrepreneurship. Journal of Business Ethics, 55:13-30.

Kuratko, D.F., Goldsby, M.G. \& Hornsby, J.S. 2004. The ethical perspective of entrepreneurs: An examination of stakeholder salience. Journal of Applied Management and Entrepreneurship, 9(4): 19-42.

Longenecker, J.G. 1988. Egoism and independence: Entrepreneurial ethics. Organizational Dynamics, Winter: 64-72.

Longenecker, J.G., McKinney, J.A. \& Moore, C.W. 1989. Ethics in small business. Journal of Small Business Management, January: 27-31.

Longenecker, J.G. \& Schoen, J.E. 1975. The essence of entrepreneurship. Journal of Small Business Management, 13.

McGrath, R.G. \& MacMillan, I. 2000. The entrepreneurial mindset: Strategies for continuously creating opportunity in an age of uncertainty. Boston: Harvard Business School Press.

McVea, J.F. 2009. A field study of entrepreneurial decisionmaking and moral imagination. Journal of Business Venturing, 24: 491-504.

Mitchell, R. K., Agle, B. R. \& Wood, D.J. 1997. Toward a theory of stakeholder identification and salience: Defining the principle of who and what really counts. Academy of Management Review, 22(4): 853-886.

Morris, M.H., Schindehutte, M., Walton, J. \& Allen, J. 2002. The ethical context of Entrepreneurship: Proposing and testing a developmental framework. Journal of Business Ethics, 40(4): 331-361.

Neubaum, D., Mitchell, M., \& Schminke, M. 2004. Firm newness, entrepreneurial orientation, and ethical climate. Journal of Business Ethics, 52: 335-347.
Paine, L.S. 1994. Managing for organizational integrity. Harvard Business Review, March/April: 106-117.

Palmer, E. 2003. US entrepreneurial activity continues to lag, study finds. Knight Ridder Tribune Business News, August 14. [Online]. Available: http://findarticles.com/p/ articles/mi_hb5553/is_200308/ai_n21510535. Accessed on 26 June 2008.

Payne, D. \& Joyner, B.E. 2006. Successful US entrepreneurs: Identifying ethical decision-making and social responsibility behaviors. Journal of Business Ethics, 65: 203-217.

Phillips, R. \& Freeman, R.E. 2003. Stakeholder theory and organi-zational ethics. San Francisco: Berrett-Koehler Publishers.

Reidenbach, R.E. \& Robin, D.P. 1991. A conceptual model of corporate moral development. Journal of Business Ethics, 10(4): 273-284.

Rutherford, M.W., Buller, P.F. \& Stebbins, J.M. 2009. Ethical considerations of the legitimacy lie. Entrepreneurship Theory and Practice, July: 949-964.

Sarasvathy, S.D. 2001. Causation and effectuation: Toward a theoretical shift from economic inevitability to entrepreneurial contingency. Academy of Management Review, 26(2): 243-288.

Sarasvathy, S.D., Simon, H.A. \& Lave, L.B. 1998. Perceiving and managing business risks: Differences between entrepreneurs and bankers. Journal of Economic Behavior and Organization, 33(2): 207-226.

Schramm, C.J. 2006. The entrepreneurial imperative: How America's economic miracle will reshape the world (and change your life). New York: HarperCollins.

Shane, S. \& Venkataraman, S. 2000. The promise of entrepreneurship as a field of research. Academy of Management Review, 25(1): 217-226

Small Business Administration. 2008. The small business economy 2007: A report to the president. [Online]. Available: http://www.sba.gov/advo/research/sb_econ2007.pdf. Accessed on 27 June 2008.

Smith, P.L. \& Oakley, E.F., III. 1994. A study of the ethical values of metropolitan and non-metropolitan small business owners. Journal of Small Business Management, October: 17-27.

Teal, E.J. \& Carroll, A.B. 1999. Moral reasoning skills: Are entrepreneurs different? Journal of Business Ethics, 19(3): 229-240.

Trevino, L.K. 1986. Ethical decision making in organizations: A person-situation interactionist model. Academy of Management Review, 11: 601-617.

Treviño, L.K., Brown, M., \& Pincus-Hartman, L. 2003. A qualitative investigation of perceived executive ethical leadership: Perceptions from inside and outside the executive suite. Human Relations, 56(1): 5-37.

Treviño, L.K. \& Weaver, G.R. 2001. Organizational justice and ethics program follow through: Influences on employees' helpful and harmful behavior. Business Ethics Quarterly, 11(4): 651-671.

Trevino, L.K., Weaver, G.R. \& Reynolds, S.J. 2006. Behavioral ethics in organizations: A review. Journal of Management, 32: 951-990.

Treviño, L.K. \& Youngblood, S.A. 1990. Bad apples in bad barrels: A causal analysis of ethical decision-making behavior. Journal of Applied Psychology, 75: 378-385. 
US Newswire. 2003. Secretary of Labor Elaine L. Chao addresses businesswomen at Women's Entrepreneurship in the 21st Century Summit. [Online]. Available: http:// findarticles.com/p/articles/mi_hb5554/is_200309/ai_ n21824377. Accessed on 26 June 2008.

Vanderkerckhove, W. \& Dentchev, N.A. 2005. A network perspective on stakeholder management: Facilitating entrepreneurs in the discovery of opportunities. Journal of Business Ethics, 60: 221-232.

Victor, B. \& Cullen, J.B. 1988. The organizational bases of ethical work climate. Administrative Science Quarterly, 33: 101-125.

Vyakarnam, S., Bailey, A., Myers, A. \& Burnett, D. 1997. Towards an understanding of ethical behaviour in small firms. Journal of Business Ethics, 16: 1625-1636.

Weaver, G., Treviño, L.K., \& Cochran, P. 1999a. Corporate ethics practices in the mid-1990s: An empirical study of the Fortune 1000. Journal of Business Ethics, 18(3): 283-294.

Weaver, G.R., Treviño, L.K., \& Cochran, P. 1999b. Corporate ethics programs as control systems: Influences of executive commitment and environmental factors. Academy of Management Journal, 42(1): 41-57.

Weber, J. 1996. Influences upon managerial moral decision making: Nature of the harm and magnitude of consequences. Human Relations, 49(1): 1-21

Weber, J. \& Green, S. 1991. Principled moral reasoning: Is it a viable approach to promote integrity? Journal of Business Ethics, 10(5): 325.

Welsh, D.H.B. \& Birch, N.J. 1997. The ethical orientation of US small business decision makers: A preliminary study. Journal of Small Business Strategy, 2: 41-51.
Wempe, J. 2005. Ethical entrepreneurship and fair trade. Journal of Business Ethics, 60: 211-220.

Wilson, E. 1980. Social responsibility of business: What are the small business perspectives? Journal of Small Business Management, July: 17-24.

Zahra, S.A. 1991. Predictors and financial outcomes of corporate entrepreneurship: An exploratory study. Journal of Business Venturing: 6(4): 259.

Zhang, Z. \& Arvey, R.D. 2009. Rule breaking in adolescence and entrepreneurial status: An empirical investigation. Journal of Business Venturing, 24: 436-447.

\section{Address correspondence to:} Melissa S. Baucus

University of Louisville

College of Business

2301 South Third Street

Louisville, KY, USA 40208

e-mail:m.baucus@louisville.edu Philip L. Cochran Indiana University

Kelley School of Business

801 West Michigan Street Indianapolis, IN, USA 40202 e-mail: plcochra@indiana.edu 
Reproduced with permission of the copyright owner. Further reproduction prohibited without permission. 